\title{
CORPORATE VALUATION: A LITERATURE REVIEW
}

\author{
By \\ Jimmy Torrez \\ Associate Professor \\ Graduate School of Business Administration \\ Rio Piedras Campus \\ University of Puerto Rico \\ Mohammad Al - Jafari \\ Managing Director \\ Jordan Deposit Insurance Corporation (JODIC) \\ Amman Jordan
}

\author{
Ahmad H Juma'h \\ Professor \\ School of Economics \\ Metropolitan Campus \\ Inter American University of Puerto Rico
}

\begin{abstract}
This article discusses the ways and methods of corporate valuations that include the discounted cash flow models, the Capital Asset Pricing Model (CAPM) and Arbitrage Pricing Models (APM), Tobin's q, sales accelerator and cash flow models of investment, and economic base performance measures such as Economic Rent and Excess Market Value. It seems that more innovated methods to detect changes in companies' financial positions are needed. Also, managers' financial experiences are essential for companies to compete in a world with a constant change.
\end{abstract}

\section{Introduction}

The corporate finance theories and practices have evolved since the 50's from normative to positive approaches to explain why and how investors react to companies' decisions and announcements with respect to companies' financial and investment decisions. The ways and 
methods used to estimate companies' values are essential issues in corporate finance. Several events during the last years have changed the validity of the models and methods of corporate valuations. The case of Enron is one of these events that make us reevaluate the classical and neoclassical methods. The aim of this article is to discuss the current corporate valuation methods.

In considering the financial valuation models, the second section deals with the most basic levels of valuation that include discounted cash flow models, under these types the models of value the company is simply the net present value of some measure of future cash flow. To link between market risk and equity returns, the Capital Asset Pricing Model (CAPM) and Arbitrage Pricing Models (APM) are frequently used in corporate valuation.

A variety of investment decisions can add value to companies. The third section discusses the basic investment models that include a neo-classical model of investment. This type of model relates the desired capital stock to interest rates, output, and capital asset cost and tax policies. Tobin's q, sales accelerator and cash flow models of investment are measures used to explain the relation between investment and companies' value. The Weighted Cost of Capital (WACC) concept is also used to explain how the value of a company to its shareholders can be manipulated by changing the proportion used among alternative methods of financing investment projects.

There are several models that incorporate economic base performance measures. The forth section covers aspects with respect to the growth potential measures of companies' value. Under this type of model the value of the company is determined by its ability to generate Economic Rents (ER). Economic Rent represents the economic profit that companies generate after deducting all costs including opportunity costs. It is predicted that when a company generates ER it will enjoy Excess Market Value (EMV). Excess market value is the added valuations a company receives relative to other companies with similar risk characteristics, but who do not generate ER.

\section{Discounted Cash Flow Models}

Valuation models based on the discounted cash flow concentrate on valuation by reference to one of several expected cash-flow proxies. These include dividends, cash flow and accounting earnings. In a perfect world these variables should produce identical results; however 
the empirical examination provides varying results because different variables suggest different estimates of expected future cash flows and, thus, different market value.

The most basic of these models can be written as follows.

$$
P=\frac{C F_{1}}{(1+r)}+\frac{C F_{2}}{(1+r)^{2}}+\frac{C F_{3}}{(1+r)^{3}}+\ldots+\frac{C F_{\infty}}{(1+r)^{\infty}}
$$

Where:

$\mathrm{P}$ is the price of the stock;

$\mathrm{CF}_{\mathrm{i}}$ is the expected cash flow in period $\mathrm{I}$;

$r$ is a constant discount rate of investors.

The majority of empirical studies examining this model use a finite ex-post approach to equate cash flow measures to returns as opposed to the stock price. The results seem to depend on the measure of cash flow chosen and the specification of the model as well as the time interval used.

For short time intervals the average explanation of market return produced by the earnings variable is about 5\% (Lev 1989). Dividend yields are also found to explain a small portion of the variance of cross sectional returns [Kenneth (1982), Fama and French (1988), and Lone, Abeyratna, Power and Sinclair (1996)]. Fama and French (1988, 2001), for example, report evidence that dividend yields typically explain a small portion of the variance of monthly or quarterly returns. Accounting cash-flow information is also found to be trivial, specifically in conjunction with the earnings [Rayburn (1986), Bowen, Burstahler and Daley (1986), Wilson (1986, 1987), Livnat and Zarwin (1990), Chitou and Ketz (1991), Ali (1994), Ali and Pope (1995), Beneda (2003), Adsera and Viñolas (2003)].

As the time interval increases there is less measurement error and noise and as a result the explanatory power increases. When Lev (1989) regresses five year returns against the corresponding five year percentage change in accounting earnings the explanatory power increase from 5\% to 35\%. Easton, Harris and Ohlson (1992) confirm these findings using the levels of earnings as determinants of returns, with earnings aggregated over varying time intervals. The ten, five, two and one year intervals have explanatory powers of $63 \%, 30 \%, 15 \%$ and $6 \%$ respectively. Fama and French (1988) report similar findings with respect to dividends. They 
report evidence that the same variable explains more than $25 \%$ of the variance of four-five year returns as compared to the monthly and quarterly results of $5 \%$.

Strong and Walker (1993) suggest that the low explanatory value of the return/earnings relationship is attributed to restricted research designed in early studies. They improve the standard returns/earnings model explaining abnormal returns by changes in earnings, using the following procedures:

-Including the levels and the changes of earnings variables in the model;

-Allowing the association parameters to vary across years and across companies;

-Allowing the association parameters to vary across components of earnings to account for differences in the degree of persistence.

The empirical examination of the improved model reveals a higher explanatory value, the adjusted R-squared increases from $10 \%$ for earnings alone to $38 \%$ for the full model. However, the work does not explain the causes of inter-temporal and cross sectional variations, nor does it identify the economic factors responsible for these variations.

Collins and Kothari (1989) examine the instability of the Earnings Response Coefficient (ERC) across years and cross companies. The analysis regresses raw returns on changes in earnings per share deflated by the beginning of period share price. The findings of the study suggest that:

-ERC is positively related to earnings persistence and economic growth opportunities; -ERC is negatively related to the interest rate levels through time and to the CAPM risk premium in the cross sectional analysis;

-The relationship between the changes in earnings and returns appears to be less sensitive to risk difference when percentage changes in earnings are used.

Easton and Zmijewiski (1989) examine the causes of cross sectional variations in the ERCs. The tests are based on a model that allows for cross sectional variation in parameters that they found to have a positive correlation between ERCs and earnings persistence measures. When they control for earning persistence, the correlation between ERC and risk, as measured by the CAPM beta, is found to be negative, but not significant in all tests.

Board and Walker (1990) examined the relationship between unexpected accounting rates of return and abnormal return for 193 December-year-end companies over the period of 19651982. They examine two measures of accounting rates of return: (i) earnings deflated by 
opening net book value of ordinary shares; and (ii) earnings deflated by opening book value. The dependent variable used is abnormal returns as calculated by using the Abnormal Performance Index (API) over a twelve-month window with two months of delay after the fiscal year end to reflect announcement delay. They find significant cross sectional and inter-temporal variation of the returns/earnings relationship. In addition, they find evidence that unexpected components of inflation appear to influence the return-earnings relationship.

Theoretically this model has been extended to fit the believed lifecycle of the company. In this way the theory can account for different growth rates in the infancy of the company, the "maturity" stage of the company, and the decay of the company. The assumption of constant cost of capital over a longer period of time reflects the simplification of the companies' values.

$$
P_{0}=\sum_{t=1}^{n_{1}} \frac{C F_{t}}{(1+r)^{t}}+\sum_{t=n_{1}+1}^{n_{2}} \frac{C F_{t}}{(1+r)^{t}}+\sum_{t=n_{2}+1}^{n_{3}} \frac{C F_{t}}{(1+r)^{t}}
$$

Another theoretical extension of the neo-classical discounted cash flow models is a Dividend Growth Model (DGM). The key assumptions of the model are: dividends grow at a constant rate, companies use their cost of capital as a discount rate, and the growth rate of the company must exceed its cost of capital.

$$
P_{0}=\frac{D_{0}(1+g)}{(1+k)}+\frac{D_{0}(1+g)^{2}}{(1+k)^{2}}+\frac{D_{0}(1+g)^{3}}{(1+k)^{3}}+\ldots+\frac{D_{0}(1+g)^{\infty}}{(1+k)^{\infty}}
$$

Since $\mathrm{g}>\mathrm{k}$ the above can be reduced to the following simple equation.

$$
P_{0}=\frac{D_{0}(1+g)}{k-g}=\frac{D_{1}}{k-g}
$$

Where:

$\mathrm{P}_{0}$ is the value of the stock in period zero;

$\mathrm{D}_{\mathrm{i}}$ is the value and dividend in period $\mathrm{i}$;

$\mathrm{g}$ is the constant growth rate of the company; and

$\mathrm{k}$ is the cost of capital of the company

Major criticisms of DGM include the assumption of constant growth (g) and the fact that the model does not allow the cost of capital to exceed the growth rate. The latter is undoubtedly not true for companies with low growth. Another major criticism is that the model does not 
apply to companies who do not pay dividends. Most companies in the USA do not pay dividends (Baker \& Powell, 1999; Keown et al., 2002.)

The majority of empirical work regarding DGM involves estimating the cost of capital (k). Geykdajy (1981) examine the trend of the cost of equity for 28 U.S. multinational companies and 28 other domestic U.S. companies over the period of 1965-1978 using the DGM approach based on the anticipated ex-ante dividends. Siegel (1985) derives a simple approximation to estimate the cost of capital using DGM with less restrictive assumptions. The assumptions are: growth rates are constant; dividend yield and growth must be calculated on a yearly basis to estimates yearly costs; and the price is based on ex-dividend quotations. The main results of this study indicate that the cost of capital is sensitive to the choice of data.

Scott (1992) measured the real cost of equity capital from 1927-1987 using DGM. He found the real growth rate of dividends to be the dominant factor that affects the real cost of capital. Cost of capital was estimated to be $4-6 \%$ nominally and $1-2 \%$ in real terms. These estimates do not correspond to actual equity returns. More realistic estimates of the cost of capital are obtained from CAPM, which will be discussed in the next section.

\section{Capital Asset Pricing Model (CAPM)}

The Capital Asset Pricing Model postulates a simple linear relationship between expected rate of return and systematic risk of a security or portfolio. The model is an extension of Markowitz's (1952) portfolio theory. The researchers who are commonly credited with the development of CAPM are Sharpe (1964), Linter (1965) and Black (1972), which is why CAPM is commonly referred to as SLB model.

Markowitz (1952) developed a concept of portfolio efficiency in terms of the combination of risky assets that minimizes the risk for a given return or maximizes return for a given risk. Using variance of expected returns as the measure of risk, he shows a locus of efficient portfolios that minimize risk for a given rate of return.

The Capital Asset Pricing Model equation shows the relationship between cost of capital and market returns and takes the following form,

$$
E\left(R_{i}\right)=R_{f}+\beta_{i}\left(E\left(R_{M}\right)-R_{f}\right)
$$

Where:

$\mathrm{E}$ is the expectation operator;

$\mathrm{R}_{\mathrm{i}}$ is the return on equity or portfolio $\mathrm{i}$; 
$\mathrm{R}_{\mathrm{M}}$ is the return on the market portfolio;

$\mathrm{R}_{\mathrm{f}}$ of the risk-free asset;

$\beta_{\mathrm{i}}$ is a measure of systematic risk on equity or portfolio $\mathrm{i}$.

The equation indicates that the expected rate of return on asset $i$ is equal to the rate of return on the risk-free asset plus a risk premium. This is simply a multiple $(\beta)$ of the difference between the expected rate of the return of the market portfolio and the risk-free rate.

Most empirical examinations of CAPM use realized returns to estimate the $\beta$ coefficient. The estimation is usually carried out by regressing a securities' excess return $\left(\mathrm{R}_{\mathrm{i}}-\mathrm{R}_{\mathrm{f}}\right)$ on market excess return $\left(\mathrm{R}_{\mathrm{m}}-\mathrm{R}_{\mathrm{f}}\right)$. In recent years CAPMs ability to predict returns has been found to be negligible [Fama and French $(1992,1993,1996)]$. However, $\beta$ is still widely acceptable as a measure of risk [Coates, et al. (1995), and Green et al. (1996)]. As such $\beta$ is commonly used to estimate Excess Return (ER) and cost of capital. As stated above the CAPM prediction of cost of capital seem to be more realistic than that of DGM.

\section{Arbitrage Pricing Theory (APT)}

Arbitrage Pricing Theory (APT), developed by Ross (1976), suggests that value return depend on several independent factors rather than a single factor of systematic risk. When these types of models include beta from CAPM they are some time referred to as extended CAPM. When beta is excluded they are simply called Arbitrage Pricing Models (APM). A major criticism of these models is that there is no theory to suggest which variables should be included and which variables excluded, and therefore the choice of variables in the past has been at adhoc.

A popular version consistent with APT is the multifactor model proposed by Fama and French (1996). Fama and French $(1992,1993,1996)$ provide evidence that CAPM does not predict returns very well. They find that market capitalization and book equity to market equity ratios predict a larger proportion of the variance in returns than does the traditional CAPM. The Model in which they settled in their 1996 paper is as follows.

$\mathrm{R}_{\mathrm{i}}-\mathrm{R}_{\mathrm{f}}=\mathrm{a}_{\mathrm{i}}+\beta_{\mathrm{t}}\left(\mathrm{R}_{\mathrm{M}}-\mathrm{R}_{\mathrm{f},}\right)+\mathrm{s}_{\mathrm{i}}(\mathrm{SMB})+\mathrm{h}_{\mathrm{i}}(\mathrm{HML})$

Where: $\mathrm{R}_{\mathrm{M}}$ is market return. 
$\mathrm{R}_{\mathrm{f}}$ is the risk-free rate.

SML is constructed by taking the return of a portfolio of companies in the bottom 50 percentile by market capitalization minus the return of a portfolio of companies in the top 50 percentile by market capitalization.

HML is constructed by taking the return of a portfolio of companies with book equity to market equity ratios in the top 70 percentile minus the return of a portfolio of companies with book equity to market equity ratios in the bottom 30 percentile.

\section{Weighted Average Cost of Capital (WACC)}

Miller and Modigliani $(1958,1963)$ demonstrated that the value of a company would be unaffected by either capital structure or dividend policy in the absence of taxes. Once corporate taxes are introduced the capital structure can influence the value of the company. Since interest payments can be deducted, the cost of external financing becomes cheaper. The assumptions used are similar to that of the frictionless world of CAPM, namely perfect information and perfect capital markets. The relevant formulas of the model are as follows

$$
K_{t o t}=K_{e}+(1-t) \frac{D}{E}\left(K_{e}-K_{d}\right)
$$

Which implies

$$
W A C C_{e}=W A C C_{t o t}\left(1+\frac{D}{E}\right)
$$

Where:

$\mathrm{K}_{\text {tot }}$ is the total cost of capital for the company;

$\mathrm{K}_{\mathrm{e}}$ is the cost of capital of equity;

$\mathrm{K}_{\mathrm{d}}$ is the cost of capital of debt;

$\mathrm{D}$ is the value of debt;

$E$ is the value of equity;

WACC $_{\text {tot }}$ is the total weighted cost of capital for the entire company; and

$\mathrm{WACC}_{\mathrm{e}}$ is the weighted cost of capital if the company did not incur debt.

Therefore, the value to equity holders will increase by a greater amount when the company incurs debt to finance new projects as compared to the use of internal finance or the issuance of new equity. In addition, the value to any existing debt holder will decrease with the issuance of new debt by the company. 


\section{Investment Models}

The neo-classical model of investment is based on an explicit model of optimization that relates the desired capital stock to interest rates, output, capital assets and tax policies. The model assumes efficient capital markets and perfect information. All companies have equal access to capital markets regardless of risk, therefore the amount borrowed and the cost of capital will only differ because of difference in investment demand. Irvin Fischer (1930) presents a more in-depth discussion of this model in his book the Theory of Interest. A summary of the theory and an empirical investigation can be found in Jorgenson (1963).

Tobin (1969) developed an investment demand model in which net investment depends on the ratio of the market value of an asset to its replacement cost. The replacement cost is represented by a "q" ratio, which is why this model is generally referred to as Tobin's q Model of Investment. This model suggests that the company will continue to invest as long as the market value of the marginal unit of capital exceeds its costs. This leads to an investment model for the company in the following form:

$$
I_{t}=a+\sum_{j=0} b_{j}(q-1)_{t-j} K_{t-j-1}+b_{k} K_{t-1}+u
$$

Where:

$\mathrm{I}_{\mathrm{t}}$ is the investment expenditure at time $\mathrm{t}$;

$\mathrm{K}_{\mathrm{t}-1}$ is the capital stock at time $\mathrm{t}-1$;

$\mathrm{K}_{\mathrm{t}-\mathrm{j}-1}$ is the capital stock at time $\mathrm{t}-\mathrm{j}-1$;

$a, b_{j}$ and $b_{k}$ and coefficients;

$\mathrm{q}$ is Tobin's q ratio.

Empirical testing of the model generally employs the average q ratio as market value instead of the marginal q as the model suggests. Hayashi (1982) justified this use by showing that under certain assumptions investment is determined by average q. The assumptions include

-The production function and adjustment cost function exhibit constant returns to scale;

-Product and factor markets are perfectly competitive; and

-The stock market is strongly efficient, which means that not even company insiders can consistently beat the market.

Ross and Schmukler (2005) and Gozzi et al (2006) examined the effects of internationalization using Tobin's q. The evidence supports models that stress that internationalization facilitates 
corporate expansion but challenge models that stress that the growth in $\mathrm{q}$ is continuous and enduring.

Sales Accelerator Models of investment developed by Jorgenson and Siebert (1968) associates the demand for capital goods to the level or changes in company's output. Under these models, things such as cost of capital and production costs have no direct effect on investment demand. Therefore the optimal stock of capital is a function of sales and investment (changes in the capital stock) are therefore some function of changes in sales.

$$
\begin{gathered}
\mathrm{K}_{\mathrm{t}}^{*}=\mu \mathrm{Y}_{\mathrm{t}} \\
\mathrm{I}_{\mathrm{it}}=\mathrm{K}_{\mathrm{i}, \mathrm{t}}-\mathrm{K}_{\mathrm{i}, \mathrm{t}-1}=\beta\left(\mathrm{Y}_{\mathrm{i}, \mathrm{t}}-\mathrm{Y}_{\mathrm{i}, \mathrm{t}-1}\right)
\end{gathered}
$$

Where

$\mathrm{I}_{\mathrm{it}}$ is the investment expenditure for company $\mathrm{i}$ at time $\mathrm{t}$;

$\mathrm{K}_{\mathrm{it}}$ is the capital stock for company $\mathrm{i}$ at time $\mathrm{t}$;

$\mathrm{K}_{\mathrm{it}-1}$ is the capital stock for company $\mathrm{i}$ at time $\mathrm{t}-1$;

$\mathrm{Y}_{\text {it }}$ is output (sales) for company $\mathrm{i}$ at time $\mathrm{t}$;

$\mathrm{Y}_{\mathrm{it}-1}$ is output (sales) for company $\mathrm{i}$ at time $\mathrm{t}-1$.

Under this specification, capital stock is adjusted instantaneously, however some empirical research allow lagged values of output to have an effect on current investment.

The last model considered is the Cash-Flow Model of Investment. Stiglz and Weiss (1981) and Myers and Majluf (1984) relax the assumption that the cost of financing does not depend on the risk of projects the company undertakes and perfect capital markets. The company's investment expenditures depend not only on the company's demand but also on the availability of funds to the company. Therefore if the company cannot cover it's investment with internal finance the company may not invest at the desired level if the cost of external finance exceeds that of internal finance. The estimation of these models is generally carried out by including cash flow as a proxy for the amount of internal funds available to the company [Fazzari, Hubbard and Perersen (1988) and Cho (1995)].

The cumulative empirical evidence indicates that investment expenditures are associated with output and cash flow conditions rather than the q ratio [Kopcke (1982), Fazzari et. al. (1988), Cho (1995), Bond and Meghir (1994) and Woods (1995)]. Therefore if the market value of new capital exceeds its book value (its costs) the company has the incentive to invest. 


\section{Growth Potential Measures of Value}

Most financial analyses concentrate on financial predictions from the current reported position from financial statements, however there is much evidence that a significant, even major, portion of the company's value can be attributed to growth potential. Excess Market Value (EMV) represents growth potential by concentrating on the surplus of the company's market value over the value of funds provided by investors. The other economic measure of value creation is Economic Rent (ER) which represents economic profit companies create from their operational activities. Economic profit differs from accounting profit in that it takes into account all costs, including opportunity cost of equity capital employed in the business. Companies that generate ER make greater profits than other companies with the same risk characteristics; therefore these companies will have excess value. We have defined this excess value as EMV. Therefore ER captures the ability of a company to access monopoly power and specific factor rents, while EMV reflects the market valuation attributed to an expected future ER. The relationship between ER and EMV is highlighted in the early work of Edwards and Bell (1961), and developed later by Peasnell (1981, 1982) and Ohlsen (1995). Edwards and Bell (1961) stated that "The meaning most frequently assigned to subjected goodwill (EMV) is that it represents the present value of above normal profits (ER)".

We can think of book value as the funds provided by the investor, and market value as the value the market puts of the company. In principle, because EMV represents the surplus of market value over book value it provides a clear indicator of value creation. Excess Return explains the earning power of existing investments and therefore it may act as a proxy for the ability of the company to add value from additional investments. Fruhan $(1979,1984)$, and Stewart $(1991,1994)$ argue that both EMV and ER have a stronger theoretical relationship to performance than traditional, but largely the empirical measures, such as market rate of return and accounting measures. These accounting measures include earnings per share (EPS), return on assets (ROA), return on investment (ROI) and return on equity (ROE). Furthermore, there are arguments that economic based measures provided a better platform for the evaluation of strategic plans than accounting measures [Rappaport (1981), Arzak (1986), Varaiya, Kerin and Weeks (1987)].

Excess Market Value and ER had been strongly advocated by the investment company Stern Stewart Financial as a measure of individual company performance. Stern Stewart 
Financial developed proprietary names for their proxies of EMV and ER. Their measure of EMV is called Market Value Added (MVA) and their measure of ER is called Economic Value Added (EVA). Stewart (1991, 1994) developed certain accounting procedures to estimate MVA from accounting data. He then argues that EVA and MVA interpret business performance using basic Microeconomic and Corporate Finance principles to track the true economic value created by management.

Stewart however, was not the first to advocate this method, Fruhan $(1979,1980,1981$, 1984, and 1988) identified and measured the value created for shareholders by a selected group of U.S. companies. Fruhan's (1979) analysis was based on comparing the market value to book value ratio and comparing it with a proxy for ER. The proxy use for ER was the difference between the average rate of return on equity and the cost of equity, which he assumed to be $10 \%$. The whole analysis was deterministic and based on the following definition:

$$
\frac{M V}{B V}=\left[\frac{1+(R O E)(R E T)}{1+k_{e}}\right]^{n}+\left[\frac{(R O E)(1-R E T)}{k_{e}-(R O E)(R E T)}\right]+\left[1-\left(\frac{1+(R O E)(R E T)}{1+k_{e}}\right)^{n}\right]
$$

Where

$\mathrm{ROE}$ is the anticipated rate of return on equity;

$\mathrm{K}_{\mathrm{e}}$ is the cost of equity capital;

RET is the projected level of future returns to be reinvested and it reflects the growth potential of the company; and

$\mathrm{N}$ is the number of years over which the returns on equity capital exceeds the cost of capital.

Fruhan's (1979) examination concluded that companies which achieved high returns of equity relative to the cost of capital and have promising investment potential have a higher market value relative to the book value. In addition, companies that earned high accounting returns on equity did not necessarily generate value.

Al-Jafari (1997) examines the theoretical relationship between EMV and ER by modifying DGM. His modifications include substituting earnings for dividends and the company's investment rate multiplied by its return on investment. The modification is as follows:

$$
M V=\frac{(1-c) E}{(k-c r)}
$$

Where: 
MV is the market value of the company;

$E$ is the expected value of the company's earnings in the next period;

$\mathrm{c}$ is the company's investment rate;

$\mathrm{r}$ is the expected return on investment; and

$\mathrm{k}$ is the company's opportunity cost of capital.

Decomposing the above equation by adding and subtracting $\mathrm{E} / \mathrm{r}$ from the right hand side then manipulating the equation yields:

$$
\begin{gathered}
M V=\frac{E}{r}+\frac{(1-c) E}{(k-c r)}-\frac{E}{r} \\
M V=\frac{E}{r}+\frac{(r(1-c)-(k-c r)) E}{(k-c r) r} \\
M V=\frac{E}{r}+\frac{(r-k) E}{(k-c r) r}
\end{gathered}
$$

Lindenberg and Ross (1981) point out that the market value of a company differs from the replacement cost of its assets by the present value of monopoly power and any company specific factor rents it enjoys. So the market value of the company can be presented as follows;

$$
\begin{aligned}
& \mathrm{EMV}=\mathrm{MV}-\mathrm{BV} \\
\Rightarrow \quad \mathrm{MV} & =\mathrm{BV}+\mathrm{EMV}
\end{aligned}
$$

Where:

$\mathrm{BV}$ is the book value of the company; and

MV is the market value of the company.

This implies that:

$$
\begin{gathered}
B V=\frac{E}{r} ; \text { and } \\
E M V=\frac{(r-k) E}{r(k-r c)} .
\end{gathered}
$$

This specification is supported, with minor modifications by the work of Peasnell (1981, 1982) and Ohlson (1995).

Varaiya, Kerin and Weeks (1987) examine the empirical validity of value based models using OLS methodology. They used Fruhan's (1979) framework to predict the relationship between profitability, growth and company value by regressing (MV/BV) on abnormal earnings, estimated by the return on equity minus the cost of capital. They also regress (MV/BV) on the 
growth rate earnings. They find the abnormal earnings and the growth coefficients were positive and statistically significance, with adjusted $\mathrm{R}^{2}$ explaining between $16 \%$ and $23 \%$ of the variance.

Lehn and Makhija (1996) study the relationship between various performance measures and stock returns. They collected data on the EVA and MVA that Stern Stewart and company published in various sources for 241 large U.S. companies over four years: 1987, 1988, 1992, and 1993 to consider the relationship between the performance measures: ROA, ROE, ROS, EVA, MVA, and market return. They find that all these measures are positively correlated with market return, but EVA has a higher correlation with returns that any other measure. They also study the effects that qualitative characteristics of the company have on the performance measures of EVA and MVA. They find that EVA and MVA are inversely related to CEO turnover in the company. In addition, they find that companys who concentrate on their core business have higher values of EVA and MVA than their less focused counterparts.

Al-Jafari (1997) tests the relationship between ER and EVA. Using 155 UK-quoted companies in six industries, he estimates ER using the difference between actual earnings and the cost of capital predicted by CAPM. He estimates EMV by taking the difference between market value and book value. His findings are summarized as follows:

- Under two alternative assumptions, constant growth and clean surplus relation, EMV of the company can be expressed in terms of ER;

- ER explains a significant portion of the variation in the levels of EMV.

- ER and company exploitation of investment potential provide a strong explanation of market return, the explained variance is much higher than that explained by traditional accounting based return model;

- The levels of ER have a higher explanatory power for EMV changes relative to changes in ER, despite the fact that the latter is apparently the logical variable obtained from direct transformation;

- Company exploitation of investment potential is at least as important as its contemporary performance in value and return determination;

- Inter-temporal variations in the suggested association between EMV-ER and company explication of investment potential are related to inflation, interest rates, business cycle stages and risk premium changes; 
- Cross-sectional and cross-industrial variation in the association are related to competition in the product market and growth potential;

- Based on their EMV, the competitive advantage and monopolistic power of large U.K.-quoted companies are weaker than their levels in the mid-eighties.

- Investment expenditures related to sales changes and product market conditions more than to the cost of capital, the U.K. companies' ability to respond to investment opportunities is unlikely to be liquidity constrained.

\section{Conclusion}

Multiple theories of corporate valuation have been examined in this paper. Although, empirically there is not a clear-cut winner, it seems that this area of study is going in the direction of performance based measures to explain valuation. This is not to say that other theories have not made major contributions to an understanding of what adds value to the company. In fact, the majority of empirical studies often use assumptions from other theories of valuation when testing the predictions in the theory in question. For example, to estimates ER the majority of empirical work uses the CAPM framework to estimate cost of capital.

Performance based measures are intellectually attractive because of the use of Microeconomic and Corporate Finance theory to explain valuation. The theory is still in its infancy; however at this early stage it seems to provide a better explanation of valuation than theories that rely on accounting based measures of performance.

\section{References}

Adsera, X. and Viñolas, P., (2003, , March/April), "FEVA: A Financial and Economic Approach to Valuation", Financial Analyst Journal, 59(2).

Ali, A. and Pope, P. E., (1995), "The Incremental Information Content of Earnings, Funds Flow and Cash Flow: The UK Evidence”, Journal of Business Finance and Accounting, 22(1), 121126.

Ali, A., (1994, Spring), “The Incremental Information Content of Earnings, Funds Flow and Cash Flow", Journal of Accounting Research, 32, 61-74

Al-Jafari, M., (1997), "Stock Market Valuation of Company Performance and Growth Potential: A Study of Value Creation and Investment", Doctoral Thesis, Manchester Business School, Manchester University, UK. 
Anomalies, Journal of Finance, 51, 55-84.

Arzak, E. R., (1986), “Do Your Business Units Create Shareholder Value”, Harvard Business Review, (Jan-Feb), 121-126.

Baker, H. K. and Powell, G. E., (1999), How corporate managers view dividend policy?. Quarterly Journal of Business and Economics, 38 (2), 17-27.

Beneda, N. L., (2003, May), "Estimating free cash flows and valuing a growth company" Journal of Asset Management. 4(4).

Black, Fisher, (1972, July), "Capital Market Equilibrium with restricted Borrowing", Journal of Business, 45, 444-455.

Board, J. L. G. and Walker, M., (1990), “Capsules and Comments: Inter-temporal and Cross Sectional Valuation in the Association between Unexpected Accounting Rates of Return and Abnormal Returns, Journal of Accounting Research, 28(1), 182-192

Bond, S. R. and Meghir, C., (1994), "Dynamic Investment Models and the Company's Financial Policy”, Review of Economic Studies, 61, 197-222.

Bowen, R., Burstahler, D. and Daley, L. A., (1986), "Evidence on the Relationship between Earnings and Various Measures of Cash Flow", The Accounting Review, 4, 713-725.

Chitou, A. and Ketz, E., (1991), "An Empirical Examination of Cash Flow Measures", ABACUS, 27, 51-64.

Cho, Y., (1995, December), Company Investment Decision and Financial Constraint: An Empirical Analysis of A Panel of Korian Manufacturing Companys", Applied Economics Decision Paper Series, No 177, Institute of Economics and Statistics, University of Oxford, UK.

Coates, J. B., Davies, M. L., Davies, E. W., Zafer, A., and Zwirlein, T., (1995), “Adopting Performance Measures that Counts: Changing to a Shareholders'Value Focus", Working Paper No. PR9510, Aston Business School, Aston University, UK.

Collins, D. W. and Kothari, S. P., (1989), “An Analysis of Inter-Temporal and Cross-Sectional Determinants of Earnings Response Coefficients", Journal of Accounting and Economics, 11, 143-182

Easton, P. D. and Zmijewiski, M., (1989), "Cross Sectional Variation in the Stock Market Response to Accounting Earnings Announcements", Journal of Accounting and Economics, $11(2), 117-141$

Easton, P. D., Harris, T. S. and Ohlson, J. A., (1992), “Accounting Earnings can Explain Most of Security Returns: The Case of Long Event Windows", Journal of Accounting and Economics, $15(2 / 3), 119-142$ 
Edwards, E. O. and Bell, P. W., (1961), "The Theory of Measurement of Business Income", University of California Press

Fama, E. F. and French, K. R., (1988), "Dividend Yields and Expected Stock Returns”, Journal of Financial Economics, pp.3-25.

Fama, E. F. and K. R. French, (1992), 'The Cross Section of Expected Stock Returns', The Journal of Finance, 47, 427-465.

Fama, E. F. and K. R. French, (1993) "Common Risk Factors in the Returns on Stock and Bonds.” Journal of Financial Economics, 33(1), 3-56.

Fama, E. F,, and K. R. French, (1996), Multifactor Explanations of Asset Pricing Anomalies." Journal of Finance. 51(1), 55-84.

Fama, E. F. \& French, K. R., (2001), Disappearing Dividends: Changing Company

Characteristics or Lower Propensity to Pay. Journal of Financial Economics, 60, 3-43.

Fazzari, S. M., Hubbard R. G. and Perersen, B.C., (1988), "Financial Constraints and Corporate Investments", Brooking Papers on Economic Activity, 1, 141-195.

Fruhan W. E. Jr., (1979), "Financial Strategy in the Creation, Transfer and Destruction of Shareholder Value", R. D. Irwin, Homewood, IL.

Fruhan W. E. Jr., (1980), "Levitz Furniture: A Case History in the Creation and Destruction", Financial Analysis Journal, 36(2), 25-45

Fruhan W. E. Jr., (1981), "Is Your Stock Worth its Market Value", Harvard Business Review, 59(3), 124-132

Fruhan W. E. Jr., (1984), “How Fast Should Your Company Grow?”, Harvard Business Review, 62(1), 84-93

Fruhan W. E. Jr., (1988), “Corporate Raiders: Head's off at Value Gap”, Harvard Business Review, 66(4), 63-68

Geykdajy Y. M., (1981), “Cost of Equity Capital and Risk of 28 US Multinational Corporations vs. 28 US Domestic Corporations: 1965-1978”, Management International Review, 21(1), 8994

Gozzi, Juan Carlos. Levine, Ross. Schmukler, Sergio L., (2006), "Internationalization and the Evolution of Corporate Valuation", World Bank Policy Research Working Paper 3933, June. Green, J., Stark, A. and Thomas, H., (1996), "UK Evidence on the Market Valuation of Research and Development Expenditures", Journal of Business Finance and Accounting, 23(2), 191216 
Hayashi, F., (1982), “Tobin's Marginal q and Average q: A Neo-Classical Interpretation”, Econometrica, (50), 213-224

Jorgenson, D. W. and Siebert, C. D., (1968), “A Comparison of Alternative Theories of Corporate Investment Behaviour”, American Economic Review, 58(4), 681-712

Jorgenson, D. W., (1963), “Capital Theory and Investment Behavior”, American Economic Review, 53(2), 247-259

Kenneth, M. E., (1982), "Empirical Evidence on Dividens as Signal of Company Value", Journal of Financial and Quantitative Analysis, 17(4), 2-31

Keown, A. J., Martin, J. D., Petty, J. W. \& Scott, D. F. (2002), Financial Management: Principles and applications $\left(9^{\text {th }}\right.$ ed.). New York, NJ: Prentice Hall.

Kopcke, R. W., (1982, July/August), "Forcasting Investment Spending: The Performance of Statistical Models", New England Economic Review, Boston, Mass: Federal Reserves Bank of Boston, (July/August), pp. 19-35.

Lehn, K.and Makhija, A., K (1996, May/June), "EVA and MVA as Performance Measures and Signals for Strategic Change", Strategy and Leadership, 34-38.

Lintner, John, (1965, Feb.), "The Valuation of Risk Assets and the Selection of Risky

Investments in Stock Portfolios and Capital budgets", Review Economic Statistic, 47(1), 13-37.

Livnat, J. and Zarwin, P., (1990), "The Incremental Information Content of Cash Flow Components", Journal of Accounting and Economics, 12, 25-46.

Lone, A., Abeyratna, G.Power, D. M. and Sinclair C. D., (1996), "The Stock Market Reaction to Dividend Announcement: A UK Study of Complex Market Signals”, Journal of Economic

Studies, 23(1), 33-52.

Markowitz, H., (1952), “Portfolio Selection”, Journal of Finance, 7(3), 77-91.

Miller, M. and Modigliani, F., (1958), "The Cost of Capital, Corporation Finance, and the Theory of Investment", American Economic Review, 48(3), 261-297.

Miller, M. and Modigliani, F., (1963), "Corporate Income Taxes and the Cost of Capital: A Correctio", American Economic Review, 53(3), 433-443.

Myers, S. C. and Majluf, N. S., (1984), "Corporate Financing and Investment Decision when Companys have Information that Investors do not have", Journal of Financial Economics, 13 (2), 187-221.

Ohlsen, J., (1995), "The Theory of Value and Earnings and an Introduction to the Ball and Brown Analysis”, Contemporary Accounting Research, 8(1), 1-19. 
Peasnell, K. V., (1981, June), “On Capital Budgeting and Income Measurement”, $\underline{\text { Abacus, }}$ 17, $52-67$

Peasnell, K. V., (1982), "Some Formal Connections between Economic Values and Yields and Accounting Numbers", Journal of Finance and Accounting, 9(3), 361-381.

Rappaport, A., (1981), "Selecting Strategies that Create Shareholders Value", Harvard Business Review, 59,(3), 139-149.

Rayburn, J., (1986), "The Association of Operating Cash Flow and Accruals with Security Returns", Journal of Accounting Research, 24 (Supp.), 112-133.

Ross Levine and Sergio L. Schmukler, (2005), Internationalization and the Evolution of Corporate Valuation, NBER Working Papers 11023, National Bureau of Economic Research, Inc.

Ross, S. A., (1976, December), “The Arbitrage Theory of Capital Asset Pricing”, Journal of Economic Theory, 13, 341-360.

Scott, M. F., (1992), “The Cost of Equity Capital and the Risk Premium on Equities”, Nuffed College Discussion Papers in Economics, 2, 21-32.

Sharpe, William F.,(1964, September), "Capital Asset Prices: A Theory of Market Equilibrium Under Conditions of Risk", Journal of Finance, 19(3), 425-442.

Siegel, J. J., (1985), “The Implication of DCF Methodology for Determining the Cost of Capital", Financial Management, 14(1), 46-53.

Stewart, G. B. III, (1991), “The Quest of Value”, New York, Harper Collins.

Stewart, G. B. III, (1994), "EVA:: Fact and Fantasy”, Journal of Applied Corporate Finance, $4,71-87$.

Stiglz, J. and Weiss, A., (1981), "Credit Rationing in Markets with Imperfect Information", American Economic Review, 71(3), 393-410.

Strong, N. and Walker, M., (1993), "The Explanatory Power of Earnings for Stock Returns”, The Accounting Review, 68, 385-399.

Tobin, J., (1969), “A General Equilibrium Approach to Monetary Theory”, Journal of Money Credit and Banking, 1, 15-29.

Varaiya, N. Kerin, R. and Weeks, R., (1987), “The Relationship between Growth, Profitability, and Company Value", Strategic Management Journal, 8(5), 487-497. 
Wilson G. P., (1986), “The Relative Information Content of Accrual and Cash Flow: Combined Evidence at the Earnings Announcement and Annual Report Release Date", Journal of Accounting Research, 24, 165-203.

Wilson G. P., (1987, April), “The Incremental Information Content of Accruals and Cash Flow after Controlling for Earnings", The Accounting Review, 293-322.

Woods, R., (1995), “Econometric Models of Investment: The Role of Factor Prices, q and Financial Constraints", Government Economic Service, Working Paper No. 127, Treasury Working Paper No. 69. 